\title{
The microvariation of the Spanish perfect in three varieties"
}

\section{Paz González}

University of Leiden, the Netherlands

p.gonzalez@hum.leidenuniv.nl

\section{Margarita Jara Yupanqui}

University of Nevada, Las Vegas

margarita.jara@unlv.edu

\section{Carmen Kleinherenbrink}

University of Leiden, the Netherlands

carmen.kleinherenbrink@hotmail.nl

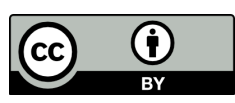

Received: 31-10-2017

Accepted: $30-05-2018$

\section{Abstract}

This study investigates the variability in the use of the Preterit canté ('I sang') and the Present Perfect he cantado ('I have sung') across three Spanish dialects: Peninsular (PEN), Peruvian (PER) and Argentinian (AR). For this purpose, we analyze the effect of type of context and temporal adverbials on the selection of these two forms. The corpus has been obtained through online questionnaires, comprising a total of thirty-two exercises that evaluate the use of the two verb forms in the following contexts: continuative, relevance of present, life experience, prehodiernal context and without temporal adverbs. The results of this research seek to contribute to the description of dialectal differences with respect to the use of the Preterit and the Present Perfect from both a quantitative and qualitative perspective.

Keywords: perfect, preterit, variability, context, Spanish

\footnotetext{
* We owe many thanks to Henk Verkuyl, Roberta d'Alessandro and Sjef Barbiers for their encouraging comments on earlier versions. We also thank Huub van den Bergh for his indispensable help with the statistical analysis. We profited very much from anonymous reviews.
} 


\section{Table of Contents}

1. Introduction

2. Grammaticalization of the Perfect

3. Previous studies on the variability of the Present Perfect in Spain, Peru and Argentina
4. Our proposal

5. Methodology

6. Analysis

7. Conclusions

\section{Introduction}

This study investigates the variability in the use of the Preterit canté ('I sang') and the Present Perfect he cantado ('I have sung') across three Spanish dialects: Peninsular (PEN), Peruvian (PER) and Argentinian (AR). For this purpose, we analyze the effect of type of context and temporal adverbials on the selection of these two forms. Our goal is threefold: (a) to examine which contexts favor the use of the perfect; (b) to explore to what extent temporal adverbs affect the selection of the perfect; and (c) to identify the semantic differences between these three varieties, according to the contexts favored by each of them.

Typically, the Present Perfect (PP) is characterized in Spanish as a structure expressing a completed situation with present relevance (Alarcos Llorach 1970; Cartagena 1999; Schwenter 1994a). In contrast, the Preterit (Pret) communicates completed situations in the past without present relevance but related to certain points of reference. The PP marks the event as located in the present and oriented to the moment of speaking. For this reason, it is not suitable for sequencing events in narrations. In contrast, the Pret encodes past situations as detached from the present, and it is used for foregrounding events in the narration and creating sequences of events in a course of events in the past. Thus, the archetypical use of the PP conveys perfect while the Pret expresses perfective aspect, (Bybee, Pagliuca and Perkins1994; Givón 1982, 2005). The PP and the Pret share the temporal semantic feature that the time of the event precedes the utterance time; but they differ in that the reference time in the Pret is aligned with the event time, whereas in the PP is aligned with the speech time (Howe 2013: 22). From the point of view of formal semantics, the semantic differentiation between these two tenses is that the PP conveys completion while the Pret marks anteriority not related to the present but related to some point of reference in the past, aorist-like (Verkuyl 1999, González 2003, González and Verkuyl 2017).

This article is organized as follows. Firstly, we summarize the historical process of grammaticalization of the PP from Classical Latin to its current form in different varieties. Secondly, we review some studies on the use of PP and the Pret forms in Peninsular, Peruvian and Argentinian varieties, and introduce our proposal. Thirdly, we explain the methodology applied to collect the data and provide information about the participants. After that, we offer the analysis of the data and the discussion. Finally, we present our conclusions. 


\section{Grammaticalization of the Perfect}

In general, grammaticalization processes have been argued to present a striking cross-linguistic consistency (Hopper and Traugott 1993). In addition, such processes are standardly assumed to be unidirectional in nature (Bybee, Pagliuca and Perkins 1994, Haspelmath 2004). Grammaticalization paths are known to be irreversible: lexical items seem to become functional items, but not the other way around. Furthermore, and more specific to our research hypotheses, even in the functional domain, morphemes expressing perfect tense will further grammaticalize into functional elements expressing perfective aspect, but not vice versa (Bybee and Dahl 1989). Possible counterexamples to unidirectionality are described as cases of degrammaticalization (Ramat 1992, Newmeyer 1998).

The original construction habere + Participle in Classical Latin initiated a grammaticalization process in Vulgar Latin, and gained new meanings in Romance Languages. González and Verkuyl (2017) discuss the difference between the Spanish Pret canté as a tense form derived from the synthetic Latin Present Perfect cantavi, and the form he cantado as an analytical form which developed from habeo cantatum. These long-term processes that took place in Romance languages have been extensively studied by Harris (1982), Pinkster (1987), Salvi (1987), Bichakjian (1988), Vincent (1988), Schwegler (1990), Ledgeway (2012) and Cennamo (2018), among others. The scheme below summarizes the evolution of the synthetic and periphrastic past forms as explained by Harris (1982:49), which distinguishes four stages in the evolution of past systems in Romance (Based on Harris 1982, Engel and Ritz 2000: 125).

2 Forms:

a) Synthetic Past, derived from the Latin Perfect (cantavi $\rightarrow$ canté)

b) Periphrastic Past, derived from the Latin resultative (habeo factum $\rightarrow$ he hecho)

4 stages:

- Stage 1: The synthetic past is used for all perfective past functions, and the periphrastic past only present states resulting from past situations. This is nowadays the case of Calabrian and Sicilian (see 1).

- Stage 2: The synthetic past is used for most of the past perfective situations, including recent past situations or a period still in progress, while the periphrastic past is used with past events with present relevance and aspectually marked as durative or repetitive (see 2, from Mexican Spanish). This use is also found in present-day/contemporary Portuguese.

- Stage 3: The synthetic past is used in past situations without relevance in the present, while the periphrastic past is used in past situations with relevance in the present (archetypical use of the perfect). This use is found in contemporary Catalan and Peninsular Spanish (see 3, from Peninsular Spanish).

- Stage 4: the synthetic past appears in past situations without relevance in the present, and only in written formal language. The periphrastic past is used in past situations, in other words, it functions in both perfect and 
perfective contexts. This is happening in Romance languages such as French, Italian and Rumanian (see 4, from French).

(1)

\section{U fici ora}

'I've just done it', lit. '...I did it now'.

Últimamente he ido mucho a Acapulco (y sigo yendo).

'Lately I've been to Acapulco a lot (and continue going there)'

(Moreno de Alba 2004:72)

Hoy he tenido un poco de fiebre (tengo escalofríos). (Kempas 2005: 524)

'I have had a little fever today (I still have chills)'

\section{J'e le vu hier/en 1980 \\ 'I saw him yesterday/in1980'}

(Cotte 1987: 101)

In each stage of the grammaticalization process, the PP has gone through semantic changes, losing some of the original semantic properties and gaining new ones. These forms may retain some of the original meaning while developing new values; thus, the old meanings and the new ones may coexist (Bybee, Pagliuca and Perkins 1994; Harris 1982; Hopper and Traugott 2003).

Through a process of erosion of the PP component of relevance (Comrie 1976: 61; Schwenter 1994a: 101), the perfect structure extends its reference to remote past context until it completes its path from perfect to perfective, as it happens in modern French (e.g. J'ai écrit un livre/'I wrote a book'). This grammaticalization path has been called "aoristic drift" (Squartini and Bertinetto 2000:404). For an exhaustive and variationist overview of the different paths the verb 'to have' has historically taken and its current use in Spanish, see Benito Moreno and Toledo y Huerta (2016).

González and Verkuyl (2017:126) hypothesize that the evolution of Spanish haber from main verb to auxiliary "(...) is part of the development of Romance tense systems into a system which can be described in terms of three tense oppositions: (i) Present vs. Past, (ii) Synchronous vs. Posterior, and (iii) Perfectum vs. Imperfective". Such a system provides room for eight Spanish tense forms:

This binary system puts the Pret in a peripheral position because it does not participate in systematic oppositions distinguishing it from the others. Thus the binary approach to the Spanish tense system reveals that in the course of time Spanish has developed from a system in which the Pret was part of a system of synthetically expressed tense forms into a system in which it has to fight for its existence due to the development of the analytic perfect forms.

An interesting factor to be taken into account when looking at the interplay between PP and Pret is the issue of the current relevance of PP: it creates the possibility to see an eventuality as completed from the point of view of relevance shared between speaker and hearer by using a present tense form. The PP can be seen as a tense form which puts completed eventualities in a present domain marked by the use of present tense forms, so that eventualities are looked 
at differently from a situation in which they are embedded in a past domain anterior to the speech situation.

In other words, Table 1 allows us to see the tense forms of Spanish as all belonging to one same system, with one outsider: the Pret. González and Verkuyl (2017) hypothesise on why the PP and Pret are both used for the same meanings in different Spanish dialects. They both follow their own grammaticalization paths, which do not need to be equal in all dialects, as it will be shown in this study with the help of three Spanish varieties.

\begin{tabular}{|c|c|}
\hline $\begin{array}{l}\text { pres } \\
\text { 1a. Presente } \\
\text { pres }(\operatorname{syn})(\operatorname{imp})\left(\ldots V_{\text {inf } \ldots)}\right. \\
\text { canto } \\
\text { ( sing) }\end{array}$ & $\begin{array}{l}\text { past } \\
1 \text { b. Imperfecto } \\
\text { past(syn)(imp)(... } V_{\text {inf...) }} \\
\text { cantaba } \\
\text { (sang) }\end{array}$ \\
\hline $\begin{array}{l}\text { 2a. Futuro Simple } \\
\text { pres }(\text { post })(\mathrm{imp})\left(\ldots \mathrm{V}_{\text {inf } \ldots)}\right) \\
\text { cantaré } \\
\text { (will sing) }\end{array}$ & $\begin{array}{l}\text { 2b. Condicional } \\
\text { past(post)(imp)(... } \mathrm{V}_{\mathrm{inf} . . .)} \\
\text { cantaria } \\
\text { (would sing) }\end{array}$ \\
\hline $\begin{array}{l}\text { 3a. Perfecto } \\
\text { pres(syn)(perf)(... } \mathrm{V}_{\text {PastP ... })} \\
\text { he cantado } \\
\text { (have sung) }\end{array}$ & $\begin{array}{l}\text { 3b. Pluscuamperfecto } \\
\text { past(syn)(perf)(... } V_{\text {PastP ... })} \\
\text { había cantado } \\
\text { (had sung) }\end{array}$ \\
\hline $\begin{array}{l}\text { 4a. Futuro compuesto } \\
\text { pres(post)(imp)(... } V_{\text {PastP...) }} \\
\text { habré cantado } \\
\text { (will have sung) }\end{array}$ & $\begin{array}{l}\text { 4b. Condicional } \\
\text { compuesto } \\
\text { past(post)(imp) }\left(\ldots V_{\text {PastP... }}\right. \\
\text { ) } \\
\text { habría cantado } \\
\text { (would have sung) }\end{array}$ \\
\hline
\end{tabular}

Table 1: The Spanish tense system binarily organized (adaptation of González and Verkuyl 2017:102)

\section{Previous studies on the variability of the Present Perfect in Spain, Peru and Argentina}

An intriguing question arises when the varieties of Spanish are taken into consideration; in particular, when Latin American Spanish (LA) and Peninsular Spanish varieties are compared. In most LA varieties (with the exception of the Andean and Peruvian Amazonian varieties), the aspectual markers seem to be going through a very different type of grammaticalization process, in which the perfective form has not only managed to maintain its position but has also gained territory over the perfect meanings.

Different studies on AR (from Buenos Aires) show that in this variety the Pret is much more frequent than the PP (De Jonge 1999: 300, Kubarth 1992: 557, Rodríguez Louro 2009: 152). With respect to its semantic readings, Kubarth (1992) distinguishes two criteria: the first criterion is temporal or affective distance. It indicates if an action started and finished in the past. The second criterion is temporal attainment. It refers to the continuation of the action until the 
moment of speaking or to its completion before the moment of speaking. Kubarth observes that in this variety temporal or affective distance is a criterion that does not have impact on the selection of the PP. However, he states that PP choice seems to be linked to actions that continue into the present. In a further study carried out by De Jonge (1999: 304), he argues that the PP highlights the deictic point but not necessarily the present relevance. De Jonge mentions that the PP can refer to moments occurred far from the time of speaking (5) and to events that have not happened in the real world.

Buenos Aires, sample 6

- ¿Se discuten ...más bien...son preguntas?

(De Jonge 1999: 303)

- No son no, no. Eh... a mí me ha tocado leer, por ejemplo, en, con...en el Congreso Internacional de Nefrología de Washington (...).

'Are they discussed... or rather... are they questions?

- No, there aren't, no, no. I had to read (with PP), for example, in, with... in the International congress of Nephrology of Washington (...)'

Rodríguez Louro (2009: 249) points out that the PP in AR appears mostly in experiential and past indefinite contexts and expresses personal experience and indefinite past reference. She proposes that in AR the PP does not establish a relation with the present but it is used instead to express indefinite past and generic reference. The PP refers to a past situation, although it does not mention a specific moment (6). It is the Pret that has the function to refer to a specific past event (7).

(6) Yo me he enamorado de tipos; me enamoro de tipos.

'I have felt in love with guys, I fall in love with guys'

(Rodríguez Louro 2009:85)

(7) Yo ayer me quemé.

(Rodríguez Louro 2009:150)

'Yesterday I burned myself'

In Peru, there is a general preference for the Pret over the PP. However, this trend is more marked in the Coastal varieties (Schumacher de Peña 1975, 1980) as exemplified in $(8)^{2}$ below:

$\mathrm{E}:$ ¿Me puedes contar eso?

S: La primera vez que me robaron, este, me parece que estaba en cuarto de media y fue una vez que me regresaba de la playa con un amigo. $Y$ este, nos bajamos en el centro de Lima, porque veníamos de Ancón. Y nos dimos cuenta que no teníamos plata para tomar el micro de allí a nuestra casas. Entonces no encontramos otra mejor idea, brillante idea, que empezar a caminar e ir caminando porque nos sabíamos la ruta. O sea, no se nos ocurrió tomar un taxi y pagarlo acá, en mi casa. Grave error.

\footnotetext{
${ }^{2}$ An anonymous reviewer mentions that the Nueva Gramática de la Real Academia Española (NGRAE 2009:23.8p: 1735) points out that this reading appears in Central America and Andean areas as well.
} 
Entonces, caminando por la avenida Brasil, ya pues, nos asaltaron. Eran tres, tres patas, con cuchillo. Y ya, pues, me robaron mis zapatillas, mi mochila. Esa fue la primera vez que me robaron. Después, después me han asaltado en un paradero. Estaba esperando una combi y un pata con una pistola me robó, me robó una cadena. Eso fue más o menos al paso. (...)

'E: Can you explain that?

S: The first time they stole me, like, I think I was still in high school and it was a time that I was returning from the beach with a friend. And this, we got out in Lima downtown, because we were coming from Ancón. And we found out that we did not have money to take the bus from there to our home. Then we didn't find a better idea, brilliant idea, that to start walking and keep walking because we knew the way. That is, we didn't think to take a taxi and pay it here, at home. Big mistake. Then, while walking through the Brasil Avenue, then, they robbed us. They were three, three guys, with a knife. And yes, then, they stole my shoes, my backpack. That one was the first time they stole from me. After that, they robbed (with PP) me in a bus stop. I was waiting for a bus and a guy with a gun robbed me, he took my chain. This was more or less on the move. (...)'

(Jara Yupanqui 2013: 86-87)

However, in the Andean and Amazonian Spanish varieties the use of the PP is higher than in Coastal Spanish (Caravedo, 1996: 165; Howe 2006). In Amazonian Spanish, this tendency prevails and the PP even takes over the whole narration as we can see in (9). This pattern is associated with external factors such as low education level, less exposure to formal Spanish and an area of intensive language contact (Jara Yupanqui and Valenzuela 2013).

(9) He salido de acá un cuarto para las seis de la tarde. He llegado a las seis en punto. De ahí me he ido al hospital. En el hospital me han internado, el segundo día a las once me he salido. De ahi he sal... he venido el... primero de mayo. Estaba acá el... cuatro. [...] He llegado acá el cuatro. (Participant A)

'I left (PP) here at quarter to six in the afternoon. I arrived (with PP) at six o'clock. From there I went (with PP) to the hospital. At the hospital they admitted (with PP) me, the second day at eleven I left (with PP). From there I have lef... I arrived (with PP) on May 1st. I was here on the fourth [...]. I arrived (with PP) here at four'

(Jara Yupanqui and Valenzuela 2013: 51)

Howe's (2006) statistics results show the preference of Lima and Cusco varieties for the Pret. This researcher states that PER does not follow the Peninsular model of the PP grammaticalization. In PEN, the PP gradually expands its acceptance of definite past adverbials and its compatibility with foreground contexts in narratives. In contrast, in PER the PP has reorganized the notion of relevance, developing innovative uses, e.g. spatial and evidential readings (Escobar 1997). Howe (2006: 208) points out that the semantic change in the Peruvian PP is based on the extension of relevance rather than the erosion of semantic features. 
With respect to Peninsular Spanish, Hurtado González (1998) and Howe (2006) show that the PP is much more used in Spain than in the rest of the Spanish speaking world. Moreover, the use of the PP in some varieties in Spain seems to be undergoing the same grammaticalization path of other Romance languages, where the PP takes over the Pret contexts. Schwenter (1994) finds that the PP is well established in hodiernal contexts (1994: 89), like in (10). This type of context has been identified as an intermediate stage in the aoristic grammaticalization process (Squartini and Bertinetto (2000), cited by Schwenter and Torres Cacoullos (2008:8)). Also, Rodríguez Louro and Howe (2010: 165) report clear contexts of PP in remote context (see (11) below); however, they also point out that this use may be related to the epistemic profile of the verb and not to the aspectual profile.

(10) Bueno, pues hoy me he despertado a las 9 y media porque ayer estuve con mi compañera de piso hasta las 3 hablando. Y hemos desayunado un café con leche con tostadas, y nos hemos vestido rápidamente sin ducharnos porque no nos daba tiempo.(...)

'Ok, today I woke up (with PP) at half past nine because yesterday I was with my roommate talking until three. And we had (with PP) breakfast a coffee with milk and toasts, and we dressed up (with PP) quickly without taking a shower because we didn't have enough time. (...) (Barcelona 2008)

(Rodríguez Louro and Jara Yupanqui 2011: 58)

(11) Pues, bueno, soy de aquí, de Alcalá, bueno de hecho, soy...he nacido (PP) aquí.

'Well, I am from here, from Alcalá [de Henares], well, in fact, I'm...I was born (PP) here'

(Rodríguez Louro and Howe 2010: 175)

In addition, Kempas (2008) noted that the PP has been extended for perfective uses (in prehodiernal contexts). He describes the acceptance of ayer (yesterday) with PP by the Peninsular speakers who participated in his study (2006: 175). In sum, in Peninsular Spanish, it seems that the Pret is being pushed back and becoming obsolete, as already has happened in some of its dialects (cf. Schwenter 1994, Hurtado González 1998, Howe 2006), because, as in other surrounding languages, two past tense forms seem to suffice.

\section{Our proposal}

It has been shown that in PEN the PP expresses hodiernal temporal contexts, but it can also appear in prehodiernal contexts (Schwenter 1994). In AR, the PP enlarges its deictic value to highlight a situation and it can refer to remote events (De Jonge 2001). However, in PER the PP seems to extend the relevance notion in the present, so that the perfect gets used for both near-to-the-speaking-moment events and temporally remote events (Howe 2006, 2013).

In this article we show not only that the grammaticalization of the PP can go a step further across varieties of Spanish, but also that its spread can fail to overgeneralize as it is typical in other European languages (Drinka 2003). Our 
results show that there is a general gradation in the use of the perfects, where the Peninsular Spanish appears as the variety that shows traces of the grammaticalization path, followed by the Peruvian speakers and then the Argentinian variety, exhibiting a considerable difference in the spread of the PP in comparison with Peninsular Spanish. As opposed to what has been said about the grammaticalisation of the PP, this gradation reveals that the opposite seems to be taking place. The results of this study contribute to the description of dialectal differences with respect to the use of the perfect and the perfective from both a quantitative and a qualitative perspective. On the basis of the collected evidence, this study challenges one basic correlate of grammaticalization: the new form (PP) typically displaces the old form (AOR).

\section{Methodology}

Based on our review of the literature and taking into consideration the reported variation between PEN and LA varieties regarding the use of the PP and the Pret, we formulate the following hypotheses:

a. The PP is used much more often in Spain than in LA, being followed by Peruvian Spanish and finally Argentinian Spanish

b. The PP appears in Present Relevance contexts both in Peruvian and Peninsular Spanish, but not in Argentinian Spanish.

c. The PP appears in life experience contexts in the three varieties

d. In PEN, the PP appears also in prehodiernal contexts, while in LA the Pret takes over hodiernal contexts.

\begin{tabular}{|l|l|l|l|l|l|l|}
\hline & \multicolumn{2}{|l|}{ Argentina } & \multicolumn{2}{l|}{ Peru } & \multicolumn{2}{l|}{ Spain } \\
\hline \hline Edad & F & M & F & M & F & M \\
\hline Age group I (19-30) & 3 & 6 & 1 & 1 & 2 & 11 \\
\hline Age group II (31-50) & 3 & 0 & 10 & 7 & 8 & 27 \\
\hline Age group III (51-70) & 4 & 2 & 2 & 0 & 3 & 1 \\
\hline Total & 10 & 8 & 13 & 8 & 12 & 39 \\
\hline
\end{tabular}

Table 2: Participants by birthplace, sex and age group

We used a questionnaire that consisted of 32 exercises which tested the use of the Present Perfect and the Preterit in a number of contexts: resultative, continuative, of present relevance, of life experience, prehodiernal and ending up with contexts where there was no specification at the temporal level. The corpus for our study was collected via Qualtrics (a software that enables users to do online data collection); 32 exercises ( 24 sentences with a choice between the Present Perfect and the Preterit, and 8 filler sentences (with a choice between the Preterit and the Imperfect). The participants were asked to choose between one of the two verbal forms.

The 24 sentences were presented randomly and divided into the following categories according to their context: 

a. Resultative context
b. Continuative context
c. Relevance of present context
d. Life experience context
e. Prehodiernal context
f. Without temporal adverbs

Out of the 24 under scrutiny sentences, 14 sentences contained prototypical Present Perfect contexts. The resultative context (context 1), the continuative context (context 2) and the life experience context (context 4) were presented in 3 sentences each, and the relevance of the present context was present in 5 sentences (as it includes the hodiernal context ( 3 sentences) and the recent past context ( 2 sentences)). Moreover, there were also five sentences containing prehodiernal contexts (context 5) and five sentences containing contexts without temporal adverbs (context 6). The questionnaire looked as follows:

a. Resultative context (29 in the questionnaire):

(12) Todavía no de limpiar la casa.
a. han terminado
b. terminaron
'They haven't finished/didn't finish cleaning the house.'

b. Continuative context (13 in the questionnaire):

(13) Este mes el hotel y sigue estando muy ocupado.
a. ha estado
b. estuvo

'This month the hotel has been/was and is still very full.'

c. Relevance of the present context (hodiernal) (25 in the questionnaire):

(14) Esta mañana me muy temprano
a. he levantado

b. levanté

'This morning I have woken up/woke up very soon.'

d. Relevance of the present context (recent past) (16 in the questionnaire):

(15) Recién este artículo
a. he escrito
b. escribí
'I have just finished/just finished this article.' 
e. Life experience context (32 in the questionnaire):

(16) Últimamente en cambiar de trabajo

a. he pensado

b. pensé

'Lately I thought/ have thought of changing jobs.'

f. Prehodiernal context (6 in questionnaire):

(17) El domingo pasado la iglesia

a. hemos visitado

b. visitamos

'Last Sunday we have visited/visited the church.'

g. Without temporal adverbs (14 in questionnaire):

(18) Mi hermana su Carrera de Psicología

a. ha terminado

b. terminó

'My sister has finished/finished her Psychology studies.'

\section{Analysis}

In this section, we first present our results on the total frequency of PP and Pret by Spanish variety, and then we discuss the statistics obtained for each PP context. The overall numbers show that PEN uses the PP with much more frequency than the PER and AR. Table 2 below displays the frequencies of the simple and periphrastic past obtained from our survey.

\begin{tabular}{|l|l|l|l|l|l|l|l|l|}
\hline & Argentina & & Peru & & Spain & \multicolumn{3}{|l|}{ Total } \\
\hline \hline & $\mathrm{N}$ & $\%$ & $\mathrm{~N}$ & $\%$ & $\mathrm{~N}$ & $\%$ & $\mathrm{~N}$ & $\%$ \\
\hline PP & 51 & 10,6 & 199 & 41,5 & 250 & 52,1 & 500 & 34,7 \\
\hline Pret & 429 & 89,4 & 281 & 58,5 & 230 & 47,9 & 950 & 65,3 \\
\hline Total & 480 & 100 & 480 & 100 & 480 & 100 & 1450 & 100 \\
\hline
\end{tabular}

Table 3: Crossdialectal distribution of the Present Perfect and the Preterit

These results show significant differences between dialects. They situate PEN with the highest frequency of PP forms $(52,1 \%)$, PER in an intermediate position $(41,5 \%)$, and AR $(10,6 \%)$ with the lowest frequency.

\subsection{Present Perfect and Preterit distribution by type of context}

With respect to the resultative PP contexts (e.g. todavia no han terminado de limpiar la casal 'they haven't finished cleaning the house'), the examination of the differences between the three dialects mirrors the overall frequencies. PEN leads the use of PP (72\%), followed by PER (65\%) and AR (30\%) (Table 3). These results are significant. 


\begin{tabular}{|l|l|l|}
\hline Variety & $\mathrm{N}$ & $\%$ \\
\hline \hline Spain & $110^{3}$ & 72 \\
\hline Peru & 41 & 65 \\
\hline Argentina & 16 & 30 \\
\hline \multicolumn{2}{|r|}{$\mathrm{F}(3,91)=19,803, * * \mathrm{p}<, 001$}
\end{tabular}

Table 4: Distribution of Resultative PP across dialects

The frequencies obtained for the continuative PP contexts (e.g. este mes el hotel ha estado y sigue estando muy ocupado/ 'this month the hotel has been and still is really busy'), are unexpected since the advance of the grammaticalization process by which the PP takes over the Pret typically would involve the gradually disappearance of the continuative contexts (Howe 2013: 49); however, we observe that this type of context obtains a high incidence of PP in PEN. We may interpret these results as a relatively stable use of PP in continuative contexts, but that does not mean that the PP is necessarily the most common in the overall tendency. The fact that the question included a blank space followed by a present tense ...__ y sigue estando...('... and still is ...') may have favored in PEN the interpretation of a period of time that concludes before the moment of the utterance. This pattern seems to reflect the reported progressive extension of the PP from recent temporal frames to temporal remote ones. In PEN the PP seems to be more prone to be interpreted as a bounded period of time and, thus, the high number of PP incidence in this context (78\%).

The results of the PP of Present Relevance contexts (e.g. Esta mañana me he levantado muy temprano, 'this morning I have woken up very soon') show some striking differences between dialects (Table 5). PEN obtains a 37\%, followed closely by AR with a $34 \%$. However, PER clearly displays a different pattern with a percentage of $47 \%$. These differences are significant.

\begin{tabular}{|l|l|l|}
\hline Variety & N & $\%$ \\
\hline \hline Spain & 57 & 37 \\
\hline Peru & 29 & 47 \\
\hline Argentina & 19 & 34 \\
\hline \multicolumn{2}{|c|}{ F $(3,91)=2,795, * \mathrm{p}<05$}
\end{tabular}

Table 5: Distribution of Present Relevance PP across dialects

The analysis of the experiential PP contexts (e.g. He pensado en cambiar de trabajo, 'I have thought about changing jobs') present also a significant result with PEN (49\%) positioning it in first place again in the use of PP over PER $(36 \%)$ and AR (25\%).

Regarding the PP prehodiernal contexts (e.g. El domingo pasado hemos visitado la iglesia, 'last Sunday we have visited church'), the percentages show a similar pattern to the one observed for the PP of current relevance. This means that PER shows a slightly higher frequency of PP than PEN and AR, however these results are not statistically significant. The different tendency of PER in this context with respect to PEN and AR goes in hand with previous research that have revealed that the PP in PER has widened its notion of relevance making it more

\footnotetext{
${ }^{3}$ The percentages and the raw numbers are per dialect group.
} 
likely to refer to remote past situations in the narration than the PEN and AR varieties.

\begin{tabular}{|l|l|l|}
\hline Variety & N & $\%$ \\
\hline \hline Spain & 75 & 49 \\
\hline Peru & 23 & 36 \\
\hline Argentina & 14 & 26 \\
\hline \multicolumn{2}{|l|}{$\mathrm{F}(3,91)=8,463, * * \mathrm{p}<, 001$}
\end{tabular}

Table 6: Distribution of Experiential PP across dialects

\begin{tabular}{|l|l|l|}
\hline Variety & N & $\%$ \\
\hline Spain & 35 & 23 \\
\hline Peru & 19 & 30 \\
\hline Argentina & 12 & 22 \\
\hline
\end{tabular}

$\mathrm{F}(3,91)=1,733, \mathrm{p}<, 166$

Table 7: Distribution of Prehodiernal PP across dialects

In fact, both the tendency of PP of current relevance and prehodiernal contexts suggest that the change undergone in this variety does not seem to correspond to same grammaticalization path reported for PEN (Hurtado González 1998, Howe 2006). This tendency supports Howe's (2013) claim that in the Peruvian case the semantic change occurs not through semantic erosion but through the expansion of the presupposition of discourse relevance (pp. 152-153). In other words, the speakers subjectively decide the relevance between the topic of discourse and the proposition. In the Peruvian case, the notion of relevance is more flexible and allows the PP to easily accept definite temporal adverbials.

Lastly, the analysis of contexts with PP without temporal adverbials (e.g. Mi hermana ha terminado Psicología, 'my sister has finished Psychology') shows again that PER stands in an intermediate position within the observed continuum.

\begin{tabular}{|l|l|l|}
\hline Variety & $\mathrm{N}$ & $\%$ \\
\hline \hline Spain & 94 & 61 \\
\hline Peru & 23 & 36 \\
\hline Argentina & 7 & 13 \\
\hline \multicolumn{2}{|c|}{$\mathrm{F}(3,91)=10,221, * * \mathrm{p}<, 001$}
\end{tabular}

Table 8: Distribution of PP in contexts without temporal adverbials

\subsection{Temporal Adverbials and PP and Pret Choice}

The results of the resultative, continuative, experiential, and without temporal adverbials contexts corroborate that the PP is used more frequently in Spain than in Peru and Argentina. It also reflects that there is a geographical dialectal continuum in which Spain and Argentina are placed at the extremes, with Peru standing in the middle.

With respect to the present relevance meaning and acceptance of prehodiernal temporal modifiers, Spain and Argentina display a similar trend but Peru show a different one. This distribution would confirm what has been suggested in other studies: the Peruvian PP widens the current relevance meaning to remote contexts (Howe 2013) but it continues having either a temporal or 
psychological impact on the present (Jara Yupanqui 2011: 111). However, this is at odds with what one would expect from the PEN speakers. After careful consideration $^{4}$, we observed that the sentences containing present relevance contexts were not chosen carefully. A sentence such as Me la he encontrado/encontré hace dos horas ('I (have) found her two hours ago') may be perfectly hodiernal. However, the temporal information given by hace dos horas ('two hours ago') is effortlessly perfective, and as such, it explains why the PEN speakers in this study choose the PERF more often. Moreover, another type of sentence we considered pertaining to the relevance of the present context contained recién ('just'). This meaning of relevance of the present is definitely the case in LA Spanish, but this adverb has become obsolete in PEN Spanish. Taking this into consideration, the results from the PEN speakers cannot be representative of the context in question.

\begin{tabular}{|l|l|l|l|}
\hline Type of context & Spain & Peru & Argentina \\
\hline \hline resultative** & $72 \%$ & $65 \%$ & $30 \%$ \\
\hline continuative** $^{* *}$ & $78 \%$ & $56 \%$ & $48 \%$ \\
\hline experiential** & $49 \%$ & $36 \%$ & $49 \%$ \\
\hline present relevance* & $37 \%$ & $47 \%$ & $34 \%$ \\
\hline prehodiernal & $23 \%$ & $30 \%$ & $22 \%$ \\
\hline without temporal adverbials $* *$ & $61 \%$ & $36 \%$ & $13 \%$ \\
\hline
\end{tabular}

Table 9: Cross-dialectal distribution of perfects by type of perfect and absence of temporal adverbials

Additionally, in the case of Spain, the high frequency of PP tokens with no temporal adverbial contexts can be interpreted as the PP becoming the default past form. Also, although PER displays much lower frequency in the same type of contexts, the $36 \%$ of PP occurrence demonstrates that in this variety there is more flexibility to accept this form and that the constraints have relaxed or weakened in comparison to what it is observed in the Argentinian variety.

\section{Conclusions}

Overall, our results show that in the LA varieties, the PP seems to be going through a step further in its grammaticalization process which involves the emergence of more abstract meanings and therefore fails to generalize. As a result, the form that prevails is not the perfect but the perfective. In other words, the Pret encroaches the PP territory regardless of the temporal or aspectual value of the action. In (19) we see sentences extracted from the questionnaire, with their particular context within parenthesis, where one would expect the choice of the PP (because of the context), but nevertheless the preferred form in Argentina and Peru is the Pret.

\footnotetext{
${ }^{4}$ We thank one of the anonymous reviewers for pointing us out this unexpected finding.
} 
Perfect $\rightarrow$ Perfective (Peru, Argentina)

a. Últimamente pensé en cambiar de trabajo (life experience)

'Lately I thought about changing jobs'

b. Todavía no terminaron de limpiar la casa (resultative)

'They did not finish cleaning the house yet'

c. Mi hermana terminó psicología (without temporal adverb)

'My sister finished psychology'

d. Este mes el hotel estuvo y sigue estando ocupado (continuative)

'This month the hotel was and still is full'

In contrast, in PEN, the pathway seems to be from perfective to perfect. In (20) we see sentences extracted from the questionnaire, with their particular context in brackets, where, because of the context, one could expect the choice of the Pret, but nevertheless the preferred form in Spain is the PP.

Perfective $\rightarrow$ perfect

a. Esta mañana me he levantado muy temprano (relevance present)

'This morning I have woken up very early'

b. Hemos viajado por toda Europa (no temporal adverbial)

'We have travelled all around Europe'

Our study shows that there is no cross-linguistic consistency: The above study is at odds with the traditional analysis which holds that Standard Spanish has evolved like French and Dutch. The LA Spanish varieties analysed in this study do not follow the typical spread trend than the European perfect (Drinka 2003) that involves the displacing of the AOR for the PERF. LA Spanish PP and Pret have developed independently (Westmoreland 1988, de Jonge 2001). As Howe (2013) suggests, it may be the path of subjectivization, at least in Peruvian Spanish.

The Pret and the PP seem to be competing for their space in the Spanish past tense system. The PP in Peninsular Spanish follows the well-known grammaticalization path of other Indo-European languages (although not as clear cut as in other studies, such as in Schwenter and Torres Cacoullos 2008), where it seems to be becoming the default past. In Peninsular Spanish, the Pret seems to have lost many of its previous readings and handed them in to the PP. This has to be interpreted with much caution, as there is dialectal variation within the Peninsula and the most standard dialects still contain very clear and traditional cuts in its uses of the PP and the Pret. Moreover, there are also some regions in Spain (Canary Islands, Galicia, Asturias, Leon) which seem to behave like in Latin American Spanish, as shown by Serrano (1995).

What seems much more remarkable is the use of these two forms in Latin America, even more if we consider the grammaticalization paths extensively described in previous research and in the state of the art of this paper. It is not the PP but the Pret the form that is taking over past tense meanings. It is the default past tense per excellence. We have shown that it is being used in flawless perfect readings (like for example resultative and relevance of the present contexts). As González and Verkuyl (2017) argue, "it is simply occupying the place of the Perf tense form by taking over its role in the binary system" (2017:133). But there is 
also variation within the Latin American dialects. Howe (2006), Jara Yupanqui (2011), Rodríguez Louro and Jara Yupanqui (2011) indicate that in the Andean variety the Pret is the favourite form, but the PP is still present in everyday use, although marking past tense with subjective and discourse-pragmatic purpose.

Following González and Verkuyl (2017), and partly supported by our results, our prediction for Peninsular Spanish is that the Pret may end up becoming obsolete, and the PP may prevail as past tense default, as in other Romance (and Germanic) languages. In several Latin American Spanish dialects the opposite path concerning past meanings seems to be in progress: the Pret seems to be adopting the past tense properties of the expelled PP. In both cases, "a reduction of tense forms seems to be taking place" (González and Verkuyl 2017: 132) because there does not seem to be necessary to keep both a perfective and a perfect form in the past realm.

\section{References}

Alarcos Llorach, Emilio. 1970. Estudios de gramática funcional del español. Madrid: Gredos. https://doi.org/10.2307/339333

Benito Moreno de, Carlota and Octavio de Toledo y Huerta. 2016. (Eds.). En torno a 'haber': construcciones, usos y variación desde el latín hasta la actualidad. New York/ Frankfurt am Main: Peter Lang (Studia Romanica et Lingüística 46). https://doi.org/10.1515/zrp-2018-0018

Bichakjian, Bernard. 1988. Evolution in Language. Ann Arbor, MI: Karoma.

Bybee, Joan. 1994. "The grammaticalization of zero: Asymmetries in tense and aspect systems". In W. Pagliuca (ed.), Perspectives on grammaticalization, 235-254. Amsterdam: John Benjamins. https://doi.org/10.1075/cilt.109.02byb

Bybee, Joan, William Pagliuca and Revere Perkins. 1994. The evolution of grammar: Tense, aspect, and modality in the languages of the world. Chicago, London: University of Chicago Press.

Caravedo, Rocío. 1996. "Perú". In M. Alvar (ed.), Manual de Dialectología hispánica. El español de América, 152-168. Barcelona: Editorial Ariel S.A.

Cartagena, Nelson. 1999. "Los tiempos compuestos del modo indicativo". In I. Bosque and V. Demonte (eds.), Gramática descriptiva de la lengua española, 2935-2975. Madrid: Real Academia Española/Espasa Calpe.

Cennamo, Michela. 2008. "The rise and development of analytic perfects in ItaloRomance". In Thórhallur, Eythórsson (eds.), Grammatical change and linguistic theory: the Rosendal papers, 115-142. Amsterdam: John Benjamins. https://doi.org/10.1075/la.113

Cotte, Pierre. 1987. "Reflexions sur l'emploi des temps du passé en francais et en anglais a la lumiere de deux evolutions recentes du systeme verbal de l'anglais". In Contrastes: revue de L'Association pour le développement des études contrastives, 14-15: 89-163. Paris: France.

Drinka, Bridget. 2003. "The Development of the Perfect in Indo-European. Stratigraphic Evidence of Prehistoric Areal Influence.” In: Papers from the 
Workshop in Linguistic Stratigraphy and Prehistory at the Fifteenth International Conference on Historical Linguistics, Melbourne, 17 August 2001, 77-105. Amsterdam, NL: John Benjamins.

https://doi.org/10.1075/cilt.239.06dri

Givón, Talmy. 1982. "Tense-Aspect-Modality: The creole prototype and beyond". In P. Hopper (ed.), Tense-Aspect: Between Semantics and Pragmatics, 115-163. Amsterdam: Benjamins (Typological Studies in Language I). https://doi.org/10.1075/tsl.1.10giv

Givón, Talmy. 2005. Contexts as other minds. The Pragmatics of Sociality, Cognition and Communication. Amsterdam/Philadelphia: Benjamins. https://doi.org/10.1075/z.130

González, Paz. 2003. Aspects on Aspect: Theory and Applications of Grammatical Aspect in Spanish. Ph. D. thesis, Utrecht Institute of Linguistics OTS, Utrecht. 43

González, Paz and Henk J. Verkuyl. 2017. "A binary approach to Spanish tense and aspect: on the tense battle about the past". Borealis - An International Journal of Hispanic Linguistics, 6 (1): 97-138. https://doi.org/10.7557/1.6.1.4096

Harris, Martin. 1982. "The 'past simple' and the present perfect in Romance". In N. Vincent \&M. Harris, (eds.), Studies in the Romance verb: essays offered to Joe Cremona on the occasion of his 60th birthday, 42-70. London: Croom Helm. https://doi.org/10.2307/413650

Haspelmath, Martin. 2004. "On directionality in language change with particular reference to grammaticalisation". In O. Fischer, M. Norde, and $\mathrm{H}$. Perridon (eds.), $U p$ and Down the Cline, 17-44. Amsterdam/Philadelphia: John Benjamins. https://doi.org/10.1075/tsl.59.03has

Howe, Lewis. C. 2006. Cross-dialectal features of the Spanish present perfect: A typological analysis of form and function. Ohio State University, Ohio.

Hopper, Paul J. and Elizabeth Traugott. 1993. Grammaticalization. Cambridge: Cambridge University Press.

Jara Yupanqui, Margarita and Pilar Valenzuela. 2013. "El uso del perfecto en secuencias narrativas en el español peruano amazónico". Lexis XXXVII (I): 31-70.

de Jonge, Bob. 1999. "El tiempo de todos los tiempos: el uso del presente perfecto en el español bonaerense". In J.A. Samper and M. Troya (eds.), Actas del $X I$ Congreso Internacional de la ALFAL, tomo I, Las Palmas de Gran Canaria: Universidad de Las Palmas de Gran Canaria, pp. 297-304.

de Jonge, Bob. 2001. "El valor del presente perfecto y su desarrollo histórico en el español americano. In H. Perdiguero, and A. Álvarez (eds.), Estudios sobre el español de América, 838 - 847. Burgos: Universidad de Burgos.

Kempas, Ilpo. 2005. "Sobre el uso del pretérito indefinido y el pretérito perfecto en el español peninsular en acciones producidas durante el día del habla." In Revista Española de Lingüística, 35 (2): 523-549.

Kubarth, Hugo. 1992. El uso del pretérito simple y compuesto en el español hablado de Buenos Aires. In L. Traill (ed.) Scripta Philologica, 553-566. Mexico: Universidad Autónoma de México. 
Kany, Charles. 1951. American-Spanish syntax. 2nd ed. Chicago: University of Chicago.

Ledgeway, Adam. 2012. From Latin to Romance. Morphosyntactic typology and change. Oxford: OUP.

Newmeyer, Frederick J. 1998. Language form and language function. Cambridge, MA: MIT Press.

Pinkster, Harm. 1987. "The strategy and chronology of the development of future and perfect tense auxiliaries". In M. Harris and P. Ramat (eds.). Historical Development of Auxiliaries, 193-223. Berlin: Mouton de Gruyter. https://doi.org/10.1515/9783110856910.193

Ramat, Giacalone A. 1992. Thoughts on degrammaticalization. Linguistics 30: 549-560.

Ramat, Gialacone A. 1992. Grammaticalization Processes in the Area of Temporal and Modal Relations. Studies in Second Language Acquisition. 14: 297-322. https://doi.org/10.1017/s027226310001113x

Reichenbach, Hans.1947. Elements of symbolic logic. Berkeley: University of Carlifornia.

https://doi.org/10.2307/2268978

Rodríguez Louro, Celeste. 2009. Perfect evolution and change: A sociolinguistic study of the Preterit and Present Perfect usage in contemporary and earlier Argentina. Ph.D. thesis, University of Melbourne.

Rodríguez Louro, Celeste and Margarita Jara Yupanqui. 2011. "Otra mirada a los procesos de gramaticalización del perfecto en español: Perú y Argentina”. Studies in Hispanic and Lusophone Linguistics 4 (1): 55-80. https://doi.org/10.1515/shll-2011-1091

Salvi, Giampolo. 1987. "Syntactic Restructuring in the Evolution of Romance Auxiliaries". In M. Harris and P. Ramat (eds.). Historical Development of Auxiliaries, 225-236. Berlin: Mouton de Gruyter. https://doi.org/10.1515/9783110856910.225

Schumacher de Peña, Gertrude. 1975. "Observaciones sobre el sistema verbal del español andino". In Materiales descriptivos para la enseñanza del castellano como segunda lengua, 63-104. Lima: Instituto Nacional de Investigación y Desarrollo de la Educación.

Schumacher de Peña, Gertrude. 1980. "El pasado en el español andino de Puno/Perú". In H. D. Bork , A. GreiveandD. Woll (eds.), Romanica Europea et Americana. Festschrift für Harri Meier, 553-558. Bonn: Bouvier.

Schwegler, Armin. 1990. Analiticity and Sintheticity. A Diachronic Perspective with Special Reference to Romance Languages. Berlin/New York: Mouton de Gruyter. https://doi.org/10.1515/9783110872927

Schwenter, Scott. A. 1994. "The grammaticalization of an anterior in progress: evidence from a peninsular Spanish dialect". Studies in Language 18: 71111. https://doi.org/10.1075/s1.18.1.05sch 
Schwenter, Scott. A. and R. Torres Cacoullos 2008. "Defaults and indeterminacy in temporal grammaticalization: The 'perfect' road to perfective". Language Variation and Change 20: 1-39.

https://doi.org/10.1017/s0954394508000057

Serrano, María José. 1995. "Sobre el uso del pretérito perfecto y pretérito indefinido en el español de Canarias: pragmática y variación”. Boletín de Filología (Universidad de Chile) 35: 533-566.

Verkuyl, Henk.J. 1999. Aspectual Issues. Studies of time and quantity. California: CLSI Publications, Standford University.

Verkuyl, Henk. J. 1993. A Theory of Aspectuality. The Interaction between Temporal and Atemporal Structure. Volume 64 of Cambridge Studies in Linguistics. Cambridge: Cambridge University Press. https://doi.org/10.1017/cbo9780511597848

Vincent, Nigel. 1982. "The development of the auxiliaries habere and esse in Romance". In N. Vincent and M. Harris (eds.), Studies in the Romance verb: essays offered to Joe Cremona on the occasion of his 60th birthday, 71-96. London: Croom Helm.

Westmoreland, Maurice.1988. "The distribution and the use of the present perfect and the past perfect forms in American Spanish". Hispania 71: 379-384.

https://doi.org/10.2307/343085

Winkel, Allard, te. 1866. Over de wijzen en tijden der werkwoorden. De Taalgids, 8. Leiden. 
